\title{
KEMAMPUAN GURU MENGIMPLEMENTASIKAN KTSP PADA SD DI KECAMATAN DETUKELI KABUPATEN ENDE
}

\section{TEACHERS' ABILITY TO IMPLEMENT THE SCHOOL CURRICULUM (KTSP) IN ELEMENTARY SCHOOLS IN DETUKELI SUB-DISTRICT OF ENDE}

Ferdinandus Etuasius Dole, Udik Budi Wibowo

Universitas Flores, Universitas Negeri Yogyakarta

doleferdinan@yahoo.co.id, yube2u@yahoo.com

\begin{abstract}
Abstrak
Penelitian ini bertujuan untuk mendeskripsikan: (1) pemahaman guru tentang KTSP, (2) kemampuan guru mengimplementasikan KTSP, dan (3) ketersediaan faktor penunjang dan faktor penghambat pelaksanaan KTSP pada sekolah dasar di Kecamatan Detukeli. Penelitian ini merupakan penelitian populasi, sehingga semua guru yang menerapkan KTSP menjadi subjek penelitian. Subjek dalam penelitian ini adalah seluruh guru SD di Kecamatan Detukeli yang berjumlah 116 guru. Jenis penelitian yang digunakan adalah penelitian evaluasi diskrepansi, yang datanya dikumpulkan menggunakan angket. Data dianalisis secara deskriptif kuantitatif. Berdasarkan penelitian ini dapat diketahui bahwa pemahaman guru tentang KTSP pada sekolah dasar di Kecamatan Detukeli, Kabupaten Ende masih rendah, dengan skor rata-rata tingkat pemahaman 2,462 (dalam skala lima). Kemampuan guru mengimplementasikan KTSP yang terdiri dari: kemampuan dalam penyusunan silabus dan RPP masih rendah dengan skor rata-rata tingkat kemampuan 2,374. Kemampuan dalam pelaksanaan pembelajaran masih rendah, dengan skor rata-rata tingkat kemampuan 2,374. Kemampuan melaksanakan evaluasi kegiatan pembelajaran masih rendah, dengan skor rata-rata tingkat kemampuan 2,440. Ketersediaan faktor penunjang pelaksanaan KTSP sangat kurang.
\end{abstract}

Kata kunci: guru, KTSP, implementasi, diskrepansi.

\begin{abstract}
This study aimed to describe: (1) the teachers' understanding of KTSP, (2) teachers' ability to implement KTSP, (3) factors supporting and inhibiting the implementation of KTSP in elementary schools in the Subdistrict of Detukeli. This study is a population study, so all teachers applying the KTSP became the subjects of this research. The subjects were all elementary school teachers in the Subdistrict of Detukeli totaling 116 teachers. This study is discrepancy evaluation research, with the data collection using a questionnaire. The data were analyzed quantitative descriptively. Based on this research, it is known that teachers' understanding of the KTSP in elementary schools in the Subdistrict of Detukeli, Ende is low, with an average score of 2.462 comprehension level (on the scale of five). The teachers' ability to implement KTSP comprising the ability to prepare the syllabus and lesson plans is still low with an average score of 2.374. Their ability to implement the teaching is low, with an average score of 2.431. The ability to implement the evaluation remains low, with an average score of 2.440. The supporting factor of the implementation of KTSP is insufficient.
\end{abstract}

Keywords: teacher, KTSP, implementation, discrepancy 


\section{Pendahuluan}

Rendahnya mutu pendidikan dan relevansinya pada setiap jenjang dan satuan pendidikan, khususnya pendidikan dasar dan menengah, merupakan salah satu permasalahan pendidikan yang dihadapi oleh bangsa Indonesia saat ini. Berbagai upaya telah dan tengah dilakukan untuk meningkatkan mutu pendidikan nasional, antara lain; pelatihan dan peningkatan kompetensi guru, pengadaan buku dan alat pembelajaran, perbaikan sarana dan prasarana pendidikan, peningkatan mutu manajemen sekolah serta perubahan kurikulum. Namun demikian, berbagai indikator peningkatan mutu pendidikan belum menunjukkan peningkatan yang berarti.

Atas dasar permasalahan di atas, berbagai pihak mempertanyakan dimanakah sebenarnya letak kendala sebenarnya, dan siapakah yang bertanggung jawab serta bagaimana mengatasi keterpurukan itu. Berbagai upaya strategis yang telah dilakukan sebagaimana diuraikan di atas, dengan satu tujuan mulia yaitu memperbaiki dan mempercepat peningkatan mutu pendidikan dalam berbagai aspek.

Percepatan mutu pendidikan itu ditandai dengan adanya gerakan moral yaitu dicanangkan tahun 2003 sebagai awal tahun mutu oleh Mendiknas sekaligus sebagai refleksi efektivitas proses pembelajaran oleh tenaga edukatif yang telah dicapai pada waktu yang lalu. Sedangkan dalam jangka panjang adalah menata kembali perbaikan kurikulum yang oleh berbagai kalangan dinilai sudah kurang linear lagi dengan perkembangan zaman dan tuntutan Dunia Usaha dan Dunia Industri (DUDI).

Hal ini tercermin dari Undang-Undang Nomor 20 Tahun 2003 tentang Sistem Pendidikan Nasional, selanjutnya disingkat UU Sisdiknas, Pasal 36 Ayat (1) menyatakan bahwa "Pengembangan kurikulum dilakukan dengan mengacu pada standar nasional pendidikan untuk mewujudkan tujuan pendidikan nasional," dan ayat (2) menyebutkan bahwa "Kurikulum pada semua jenjang dan jenis pendidikan dikembangkan dengan prinsip diversifikasi sesuai dengan satuan pendidikan, potensi daerah, dan peserta didik". Pasal 38 Ayat (2) menyatakan bahwa: Kurikulum pendidikan dasar dan menengah dikembangkan sesuai dengan relevansinya oleh setiap kelompok atau satuan pendidikan dan komite sekolah/madrasah di bawah koordinasi dan supervisi dinas pendidikan atau kantor Departemen Agama kabupaten/kota untuk pen- didikan dasar dan provinsi untuk pendidikan menengah.

Dalam rangka melaksanakan perundangan tersebut, telah diterbitkan Peraturan Pemerintah No.19 Tahun 2005 tentang Standar Nasional Pendidikan (PP SNP) yang meliputi delapan standar, yaitu standar isi, standar kompetensi lulusan, standar proses, standar penilaian, standar sarana dan prasarana, standar pengelolaan, standar tenaga kependidikan, dan standar pembiayaan. Pasal 17 (Ayat 2) PP menyebutkan: Sekolah dan komite sekolah, atau madrasah dan komite madrasah, mengembangkan kurikulum tingkat satuan pendidikan dan silabusnya berdasarkan kerangka dasar kurikulum dan standar kompetensi lulusan, di bawah supervisi dinas kabupaten/kota yang bertanggung jawab di bidang pendidikan untuk SD, SMP, SMA, dan MK, dan departemen yang menangani urusan pemerintahan di bidang agama untuk MI, MTs, MA, dan MAK.

Dalam pelaksanaannya, standar isi merupakan garis besar kurikulum pendidikan secara nasional yang berisi standar kompetensi dan kompetensi dasar yang harus dikuasai oleh peserta didik selama mengikuti pendidikan. Standar Proses merupakan proses penerapan kurikulum dalam kegiatan pendidikan agar peserta didik dapat mencapai standar kompetensi yang diharapkan dalam standar isi. Setelah peserta didik menempuh pendidikan dalam fase tertentu, diadakan penilaian yang mengacu pada standar evaluasi dan penentuan kelulusannya mengacu pada standar kompetensi lulusan. Pelaksanaan proses pendidikan harus mendapat dukungan dari guru sebagai pengelola utama pendidikan yang harus memenuhi standar tenaga kependidikan, dan ditunjang oleh manajemen, sarana prasarana dan biaya yang memadai.

Gerakan peningkatan mutu pendidikan merupakan amanat utama yang harus dilakukan oleh setiap lembaga pendidikan, sebagai konsekuensinya lembaga pendidikan sebagai tempat ditumbuhkembangkan ilmu pengetahuan dan teknologi harus menyadari bahwasanya kualitas pendidikan yang telah dicapai saat ini masih jauh dari harapan masyarakat pemakai jasa pendidikan. Oleh karena itu perlu segera adanya reformasi pembelajaran untuk dapat menghasilkan sumber daya manusia yang berkualitas. Kualitas sebuah lembaga pendidikan dapat ditunjukkan oleh kualitas lulusannya secara utuh dalam seluruh tataran, baik pengetahuan, keterampilan serta sikap dan nilai sehingga dapat melanjutkan studi pada jenjang pendidikan 
yang lebih tinggi maupun dapat memasuki dunia usaha dan dunia kerja secara profesional.

Namun patut disadari bahwa masalah peningkatan mutu pendidikan merupakan hal yang kompleks dan tidak mudah dilaksanakan/ diperbaiki dalam jangka waktu yang singkat, karena melibatkan berbagai komponen pendidikan seperti sekolah, tenaga pendidikan, karyawan/i, lingkungan sekolah, visi dan misi sekolah, kepemimpinan kepala sekolah, sistem evaluasi yang dilakukan, hubungan sekolah dengan masyarakat, stakeholder, peserta didik serta manajemen sekolah yang berlaku. Hal-hal tersebut merupakan indikator substantif utama dalam mencapai tujuan yaitu menghasilkan lulusan yang baik dan bermutu.

Lembaga pendidikan dapat menjadi sumber penghasil tenaga profesional manakala lembaga pendidikan tersebut dikelolah dengan manajemen yang profesional dan kurikulum yang digunakan harus berbasis pada dunia kerja/relevan, sehingga output dan outcome yang dihasilkan mampu mengembangkan potensi dan kreativitas diri. Penerapan kurikulum di sekolah harus dapat menjadikan peserta didiknya memiliki pengetahuan, keterampilan yang memadai untuk pendidikan di tingkat selanjutnya, dan sikap yang sesuai dengan tuntutan masyarakat setempat dan global, juga memiliki kompetensi yang memadai untuk dunia kerja sesuai dengan kondisi daerahnya.

Dalam era globalisasi dan pasar bebas saat ini, masalah pendidikan dihadapkan pada berbagai perubahan yang tidak menentu. Hal ini sebagai dampak dari tidak linearnya pendidikan dengan lapangan kerja yang tersedia. Apa yang terjadi di lapangan kerja sulit diikuti oleh dunia pendidikan, sehingga terjadi berbagai kesenjangan. Menanggapai hal itu maka masalah pendidikan harus diletakkan pada empat prinsip diantaranya belajar mengetahui (learning to know), belajar melakukan (learning to do) belajar dalam kebersamaan (learning to live together) dan belajar menjadi diri sendiri (learning to be) (Delors, 1996, p.37).

Kultur yang demikian harus dikembangkan dalam dunia pendidikan sehingga pembangunan manusia seutuhnya dapat terealisasikan, karena pada akhirnya aspek kultural dari kehidupan manusia lebih penting dari pertumbuhan ekonomi. Searah dengan visi, misi dan arah Rencana Pembangunan Jangka Panjang Nasional Tahun 2005-2025 (UU No. 17 tahun 2007) yang mencerminkan cita-cita kolektif yang akan dicapai oleh bangsa Indonesia serta strategi penjabaran cita-cita berbangsa sebagaimana tercantum dalam Pembukaan Undang-Undang Dasar Negara Republik Indonesia Tahun 1945, yaitu terciptanya masyarakat yang terlindungi, sejahtera dan cerdas serta berkeadilan. Cita-cita masyarakat yang adil dan sejahtera yang tertuang dalam UUD 1945, diimplementasikan dengan terwujudnya masyarakat Indonesia yang damai, demokratis, berkeadilan, berdaya saing, maju dan sejahtera, dalam wadah Negara Kesatuan Republik Indonesia yang didukung oleh manusia Indonesia yang sehat, mandiri, beriman, bertaqwa, beraklak mulia, cinta tanah air, berkesadaran hukum dan lingkungan, menguasai ilmu pengetahuan dan teknologi, memiliki etos kerja yang tinggi dan disiplin.

Untuk mewujudkan pelaksanaan pendidikan yang baik dan berkualitas di Indonesia, maka perlu dipahami dengan benar berbagai kendala dan permasalahan pokok yang berkaitan dengan sistem pendidikan di negeri ini. Sehubungan dengan hal ini Tilaar (2002, p.4) mengatakan bahwa: Masalah pendidikan di Indonesia sedang dihadapkan dengan empat krisis pokok yang berkaitan dengan kualitas, relevansi atau efisiensi eksternal, elitisme, dan manajemen. Lebih lanjut dikemukakan pula bahwa sedikitnya ada enam masalah pokok yang berkaitan dengan sistem pendidikan nasional yaitu (1) menurunnya ahklak dan moral peserta didik, (2) pemerataan kesempatan belajar, (3) masih rendahnya efisiensi internal sistem pendidikan,(4) status kelembagaan, (5) manajemen pendidikan yang tidak sejalan dengan pembangunan nasional, (6) sumber daya yang belum profesional.

Permasalahan yang dikemukakan Tilaar di atas, perlu disikapi dengan penataan sistem pendidikan secara menyeluruh terutama yang berkaitan dengan masalah perubahan kurikulum sebagai dasar peningkatan mutu pendidikan serta relevansinya dengan dunia kerja. Berangkat dari dasar pemikiran inilah Kurikulum Tingkat Satuan Pendidikan sebagai jawaban yang bertujuan menata ulang model pendidikan sesuai dengan tuntutan perkembangan.

Penataan paradigma pendidikan baru harus diarahkan pada upaya menyiapkan peserta didik untuk memasuki dunia kerja dengan berbagai persaingannya. Dengan demikian harapan yang hendak dicapai adalah bagaimana membekali peserta didik dengan berbagai kompetensi untuk hidup sesuai dengan lingkungan dimana dia berada (life skill) sehingga mampu 
melakukan penyesuaian diri dan dapat mengatasi permasalahan kehidupannya dengan mengembangkan kompetensi yang telah dimilikinya.

Di samping itu, diberlakukan UndangUndang Otonomi Daerah nomor 32 tahun 2004 Tentang Pemerintahan Daerah, yang selanjutnya akan disebut dengan UU Otda, memberikan keleluasan kepada masing-masing daerah untuk merancang model kurikulum yang sesuai dengan kondisi dan kebutuhaan daerah masingmasing. Kurikulum yang dianggap dapat mengatasi berbagai permasalahan pendidikan adalah Kurikulum Berbasis Kompetensi (KBK) yang memberikan kesempatan kepada setiap satuan pendidikan untuk mengembangkannya sesuai situasi setempat, yang diberi nama Kurikulum Tingkat satuan pendidikan (KTSP). Pemberlakuan UU Otda berdampak pada pergeseran paradigma pengelolahan pendidikan dari sistem sentralistik menjadi sistem desentralistik. Ini berarti sekolah-sekolah diberikan kewenangan secara otonom untuk mengelola program pendidikan pada satuannya masing-masing dengan memperhatikan kebutuhan dan aspirasi serta melibatkan masyarakat pendidikan dan stake holder.

Ada tiga landasan yang menjadi dasar pemberlakuan Kurikulum Berbasis Kompetensi. Pertama, adanya pergeseran paradigma model pembelajaran dari pembelajaran kelompok ke pembelajaran individual. Dalam model pembelajaran ini setiap individu dapat belajar sendiri dan tidak menggantungkan diri pada orang lain. kedua, pengembangan konsep belajar tuntas (mastery learning) atau belajar sebagai penguasaan (learning for mastery) adalah suatu falsafah pembelajaran yang menekankan bahwa dengan sistem pembelajaran yang tetap, semua peserta didik dapat mempelajari semua bahan dengan hasil yang baik. ketiga pendefinisian kembali terhadap bakat. Untuk menjawab semuanya itu perlu kompetensi guru dalam bidangnya. Tanpa itu guru tidak mampu mengembangkan kompetensi siswa.

Dalam pelaksanaannya KBK masih belum memberikan ruang yang bebas bagi satuan pendidikan tertentu untuk mengembangkan kurikulum secara mandiri, karena dalam struktur kurikulumnya, Badan Standar Nasional Pendidikan (BSNP) tidak hanya menetapkan standar kompetensi dan kompetensi dasar secara nasional, namun juga materi pokok dan indikator pencapaian kompetensinya. Sedangkan pada KTSP, BSNP hanya menetapkan standar kom- petensi dan kompetensi dasar secara nasional, sedangkan materi pokok dan indikator pencapaian kompetensinya dikembangkan sendiri oleh satuan pendidikan yang bersangkutan.

Pengembangan Kurikulum Tingkat Satuan Pendidikan (KTSP) yang beragam mengacu pada standar nasional pendidikan untuk menjamin pencapaian tujuan pendidikan nasional. Standar nasional pendidikan terdiri atas standar isi, proses, kompetensi lulusan, tenaga kependidikan, sarana dan prasarana, pengelolaan, pembiayaan dan penilaian pendidikan. Dua dari kedelapan standar nasional pendidikan tersebut, yaitu Standar Isi (SI) dan Standar Kompetensi Lulusan (SKL) merupakan acuan utama bagi satuan pendidikan dalam mengembangkan kurikulum.

UU Sisdiknas dan Peraturan Pemerintah Republik Indonesia No 19 tahun 2005 (PP 19/2005) tentang Standar Nasional Pendidikan (PP SNP) mengamanatkan kurikulum pada KTSP jenjang pendidikan dasar dan menengah disusun oleh satuan pendidikan dengan mengacu kepada SI dan SKL serta berpedoman pada panduan yang disusun oleh Badan Standar Nasional Pendidikan (BSNP). Selain dari itu, penyusunan KTSP juga harus mengikuti ketentuan lain yang menyangkut kurikulum dalam UU Sisdiknas dan PP SNP. Panduan yang disusun BSNP terdiri atas dua bagian. Pertama, Panduan Umum yang memuat ketentuan umum pengembangan kurikulum yang dapat diterapkan pada satuan pendidikan dengan mengacu pada Standar Kompetensi dan Kompetensi Dasar yang terdapat dalam SI dan SKL. Termasuk dalam ketentuan umum adalah penjabaran amanat dalam UU Sisdiknas dan PP SNP, serta prinsip dan langkah yang harus diacu dalam pengembangan KTSP. Kedua, model KTSP sebagai salah satu contoh hasil akhir pengembangan KTSP dengan mengacu pada SI dan SKL dengan berpedoman pada Panduan Umum yang dikembangkan BSNP. Sebagai model KTSP, tentu tidak dapat mengakomodasi kebutuhan seluruh daerah di wilayah Negara Kesatuan Republik Indonesia (NKRI) dan hendaknya digunakan sebagai referensi.

Guru sebagai ujung tombak pelaksanaan kurikulum perlu dipersiapkan secara baik agar mampu menjabarkan kurikulum dengan tepat dalam proses pembelajaran. Pelatihan dan penataran baik dilakukan oleh pemerintah maupun dalam wadah Kelompok Kerja Guru (KKG) yang diperuntukan untuk guru harus komprehensip, mulai dari memahami, mengerti, 
selanjutnya mengimplementasikan dalam proses pembelajaran.

Menjadi suatu kenyataan bahwa keberhasilan pendidikan sangat dipengaruhi oleh kemampuan guru yang akan menerapkan dan mengaktualisasikan kurikulum itu. Guru harus memilki kompetensi profesional yang memadai. Kompetensi guru itu berkaitan dengan pengetahuan dan kemampuan mengaplikasikan kurikulum dalam pelaksanaan tugas yang diemban. Kegagalan perubahan kurikulum juga disebabkan karena kurangnya pengetahuan dan pemahaman guru. Kegagalan dalam pelaksanaan KTSP selain diakibatkan oleh faktor guru, juga dipengaruhi oleh komponen lainnya, seperti sistem manajemen, biaya, dan juga ketersediaan sarana prasarana.

KTSP dengan model yang agak berbeda dari kurikulum-kurikulum sebelumnya kiranya guru menjadi sentral perhatian di samping faktor-faktor lain. Kekurangan pengetahuan guru tentang kurikulum akan dapat diperbaiki bila adanya sarana berupa buku-buku yang berisi tentang kurikulum, adanya pendanaan untuk pelatihan guru. Dampak dari kurangnya pengetahuan ini, guru mengadopsi langsung model silabus yang dikembangkan oleh BNSP untuk digunakan dalam Proses Belajar Mengajar (PBM).

Penjabaran kurikulum menjadi silabus dan selanjutnya menjadi rencana pembelajaran dengan sistem evaluasi yang rumit merupakan satu pekerjaan baru bagi guru, karena selama ini guru terbiasa dengan kurikulum yang siap pakai. Terbatasnya kegiatan pelatihan dan penataran guru akibat kurangnya pendanaan kegiatan pelatihan dan penataran guru di daerah menjadi salah satu faktor pengambat pelaksanaan KTSP. Sosialisasi penjabaran KTSP ke dalam pembelajaran belum dilaksanakan secara maksimal. Para Guru memiliki pemahaman yang berbeda terhadap KTSP, terlebih pada guru yang berada di daerah pedesaan dan terpencil.

Ketersediaan fasilitas yang mendukung guru dalam mempelajari pengembangan KTSP masih sangat terbatas. Guru tidak dapat mengakses informasi aktual tentang strategi mengembangkan KTSP untuk siap diterapkan dalam pembelajaran. Guru hanya memperoleh informasi sepintas melalui para pengawas sekolah yang berkunjung ke sekolah, dan itupun dengan waktu yang sangat singkat dan frekuensi kunjungan yang sangat sedikit dalam setahun, sehingga informasi yang diperolehpun sangat terbatas. Penjelasan yang diberikan kepada guru tentang KTSP tanpa diikuti oleh petunjukpetunjuk yang jelas. Hal ini turut menyebabkan pelaksanaan KTSP di sekolah dasar belum bisa berjalan secara optimal. Guru lalu mencari buku-buku yang tersedia lalu mengadopsi silabus dari buku-buku dan contoh silabus yang ada di internet tanpa mengadaptasikan dengan kondisi sekolahnya. Keadaan ini sesungguhnya sangat tidak sejalan dengan tujuan KTSP sendiri yang memberikan kesempatan kepada sekolah untuk tidak menyesuaikan dengan kondisi sekolah setempat.

Berdasarkan penjelasan di atas maka dirasakan perlu untuk melakukan suatu kajian secara ilmiah melalui penelitian dengan judul tentang kemampuan guru mengimplementasikan Kurikulum Tingkat Satuan Pendidikan, mengingat peningkatan kualitas sekolah yang akan berimplikasi pada peningkatan kualitas pendidikan memerlukan keterlibatan semua komponen standar pendidikan.

Dalam penelitian ini, peneliti akan memfokuskan penelitian pada kemampuan guru mengimplementasikan KTSP pada sekolah dasar di Kecamatan Detukeli. Kecamatan Detukeli merupakan sebuah kecamatan di Kabupaten Ende yang jarak ibukota kecamatannya dari kabupaten sekitar $65 \mathrm{~km}$. Kecamatan dengan 10 wilayah desa ini memiliki 14 SD Negeri/Inpres maupun swasta. Jumlah sekolah tersebut terdiri dari 4 Sekolah Negeri/Inpres dan 10 Sekolah Swasta, dengan jumlah gurunya sebanyak 114 orang. Hal-hal yang akan diteliti berkaitan dengan kemampuan guru dalam penerapan Kurikulum Tingkat Satuan Pendidikan (standar isi dan standar Proses), pelaksanaan penilaian, dan faktor-faktor yang mempengaruhinya, dan selanjutnya akan mempengaruhi output atau lulusan.

\section{Metode}

\section{Jenis Penelitian}

Penelitian tentang kemampuan guru dalam mengimplementasikan Kurikulum Tingkat Satuan Pendidikan pada SD di Kecamatan Detukeli Kabupaten Ende ini menggunakan pendekatan kuantitatif deskriptif. Dari segi metode, penelitian ini menggunakan metode penelitian evaluasi dengan model kesenjangan atau model diskrepansi (discrepancy model) yang dikembangkan Malcom Provus. "Model kesenjangan atau model diskrepansi yaitu suatu model yang menekankan pada pandangan ada tidaknya kesenjangan antara tujuan program dengan pelak- 
sanaan program" (Arikunto \& Jabar, 2004, p.31 \& Widoyoko, 2009, p.4).

Waktu dan Tempat Penelitian

Penelitian ini dilakukan pada 13 SD/MI di Kecamatan Detukeli Kabupaten Ende dengan kategori SD negeri dan swasta yang ada di Kecamatan Detukeli Kabupaten Ende. Penelitian dilaksanakan pada bulan Mei-Juni 2013.

\section{Target/Subjek Penelitian}

Penelitian ini merupakan penelitian populasi, maka semua guru yang menerapkan KTSP menjadi subjek penelitian. Subjek dalam penelitian ini adalah seluruh guru SD di Kecamatan Detukeli yang berjumlah 116 guru di Kecamatan Detukeli.

Data, Intrumen, dan Teknik Pengumpulan Data

Pengumpulan data menggunakan metode angket. Kuesioner/angket. Angket yang digunakan dalam penelitian ini bersifat tertutup, artinya responden memberi jawaban dengan memberi tanda cek pada jawaban yang telah disediakan. Angket berisi 2 bagian; dimana bagian pertama berisi pemahaman guru tentang KTSP dan bagian 2 berisi Kemampuan guru dalam mengimplementasikan KTSP (pembuatan RPP dan Silabus) dan pelaksanaan kegiatan pembelajaran. Sedangkan dokumentasi dan observasi dilakukan untuk mengetahui secara lebih pasti kebenaran jawaban hasil angket.

Angket dalam penelitian untuk mengukur kemampuan guru dalam mengimplementasikan KTSP dimodifikasi dari Peraturan Menteri Pendidikan Nasional nomor 16 tahun 2007 tanggal 4 Mei 2007 tentang standar kualifikasi akademik dan kompetensi guru. Dalam angket ini hanya diambil beberapa hal yang berkaitan dengan masalah penelitian, yaitu: (1) Kemampuan menganalisis $\mathrm{SK} / \mathrm{KD}$ dalam pembuatan Silabus, untuk pembuatan indikator, penentuan tujuan pembelajaran, pemilihan materi, pemilihan metode, pemilihan media, penentuan alokasi waktu, dan perencanaan alat evaluasi kegiatan dan hasil belajar. (2) Kemampuan menghasilkan Silabus dan RPP, media pembelajaran. (3) Mengaplikasikan KTSP (Silabus dan RPP) dalam pembelajaran, dan (4) Kemampuan mengevaluasi proses dan hasil belajar.

Kemampuan atau kompetensi yang tertuang di dalam Peraturan Menteri Pendidikan Nasional nomor 16 tahun 2007 tanggal 4 Mei 2007 tentang standar kualifikasi akademik dan kompetensi guru, dan yang telah dimodifikasi ke dalam bentuk angket ini menjadi standar dalam penelitian ini untuk mengevaluasi pelaksanaan Kurikulum Tingkat Satuan pendidikan. Skor tertinggi ideal dalam angket, menjadi skor harapan yang akan dibandingkan dengan keadaan riil pelaksanaan KTSP di lapangan.

Teknik Analisis Data

Data yang diperoleh dari hasil penelitian akan dianalisis dengan teknik kuantitatif deskriptif. Penghitungan kategori pelaksanaan Kurikulum Tingkat Satuan Pendidikan yang digunakan adalah sebagai berikut:

$$
\bar{X}=\frac{\sum x_{i}}{n}
$$

Keterangan:

$\bar{X} \quad:$ Rata-rata umum responden

$\Sigma \mathrm{x}_{\mathrm{i}}$ : Jumlah rata-rata jawaban setiap responen $\mathrm{n} \quad$ : Jumlah Responden

Perhitungan rerata ini dibuat untuk masing-masing responden. Dari rerata setiap responden akan diakumulasikan untuk mendapatkan rerata umum digeneralisasikan sebagai kesimpulan. Untuk memperoleh nilai rata-rata kemampuan guru mengimplementasikan KTSP, maka dicari nilai rata-rata dari setiap komponen penelitian. Nilai rata-rata setiap komponen diperoleh dari rata-rata jumlah skor total dibagi skor maksimum dikali nilai skala 5. Secara matematis dapat dirumuskan:

$$
\overline{N i}=\frac{\sum X}{\text { skormaksimal }} \times 5
$$

Keterangan:

$\bar{N} i \quad=$ Nilai rata-rata

$\Sigma \mathrm{X}=$ Jumlah skor aktual yang diperoleh

$\Sigma \mathrm{n} \quad=$ Jumlah data

Dalam menentukan tingkat kemampuan guru dalam mengimplementasikan KTSP, maka perlu ditentukan dahulu mean ideal $\left(\bar{X}_{i}\right)$, Simpangan Baku ideal (SBi) serta skala tertinggi ideal dan skala terendah ideal (Sukardjo \& Permana Sari, 2008, p.83).

$\bar{X}_{i}=1 / 2$ (skala tertinggi ideal + skala terendah ideal)

$\mathrm{SBi}=1 / 6$ (skala tertinggi ideal-skala terendah ideal)

Dari nilai yang diperoleh baru kemudian dikonversi menjadi nilai kriteria dengan acuan seperti pada Tabel 1. 
Tabel 1. Kriteria Penilaian

\begin{tabular}{cc}
\hline Interval Nilai & $\begin{array}{c}\text { Kriteria } \\
\text { Nilai }\end{array}$ \\
\hline$\overline{\boldsymbol{X}}_{i}+1,80 \mathrm{SBi}<\mathrm{X}$ & Sangat \\
Baik \\
$\overline{\boldsymbol{X}}_{i}+0,60 \mathrm{SBi}<\mathrm{X} \leq \overline{\boldsymbol{X}}_{i}+1,80 \mathrm{SBi}$ & Baik \\
$\overline{\boldsymbol{X}}_{i}-0,60 \mathrm{SBi}<\mathrm{X} \leq \overline{\boldsymbol{X}}_{i}+0,60 \mathrm{SBi}$ & Cukup \\
$\overline{\boldsymbol{X}}_{i}-1,80 \mathrm{SBi}<\mathrm{X} \leq \overline{\boldsymbol{X}}_{i}-0,60 \mathrm{SBi}$ & Kurang \\
$\mathrm{X} \leq \overline{\boldsymbol{X}}_{i}-1,80 \mathrm{SBi}$ & Sangat \\
\hline
\end{tabular}

Dari langkah-langkah di atas, maka diperoleh kriteria penilaian yang digunakan dalam penelitian ini, yaitu dapat dilihat pada Tabel berikut.

Tabel 2. Kriteria Penilaian pada Skala 5

\begin{tabular}{cc}
\hline Interval Nilai & Kriteria Nilai \\
\hline $4,20<X$ & Sangat Baik \\
$3,40<X \leq 4,20$ & Baik \\
$2,60<X \leq 3,40$ & Cukup \\
$1,80<X \leq 2,60$ & Kurang \\
$X \leq 1,80$ & Sangat Kurang \\
\hline
\end{tabular}

Dari interval nilai yang diperoleh, maka secara deskriptif dapat ditarik kesimpulan kriteria kemampuan guru dalam mengimplementasikan KTSP.

\section{Hasil Penelitian dan Pembahasan}

Pengumpulan data penelitian tentang kemampuan guru mengimplementasikan kurikulum tingkat satuan pendidikan pada sekolah dasar di kecamatan Detukeli, dilaksanakan pada tanggal 1 Juni sampai dengan 15 Juni 2015. Kegiatan pengumpulan data dimulai dengan menyebarkan angket penelitian ke sekolah-sekolah tempat penelitian. Jumlah angket yang dibagikan sebanyak 116 eksemplar. Dari jumlah angket yang ada semua dikembalikan. Angket penelitian berisi 95 item semuanya diisi oleh responden.

Dari data penelitian yang terkumpul dapat dipaparkan gambaran tentang fokus penelitian sebagai berikut:

Pemahaman Guru tentang Standar Isi dalam KTSP

Pada komponen 1 tentang pemahaman guru terhadap standar isi dalam KTSP ada 10 item, dengan total skor ideal terendah pada komponen ini adalah 10 dan skor ideal tertinggi adalah 40. Hasil penelitian menunjukkan skor terendah jawaban responden adalah 13 dan skor tertinggi adalah 26. Dari skor tersebut dapat dihitung rata-rata terendah dari responden adalah 1,30 dan rata-rata tertinggi adalah 2,60. Total rata-rata responden dari sepuluh item pada komponen 1 penelitian ini yakni 228,80. Dari total rata-rata jawaban responden ini dibagi jumlah responden 116 .

$$
\begin{aligned}
\bar{x} & =\frac{\sum \bar{x} i}{n} \\
& =\frac{228_{,} 80}{116} \\
& =1,97
\end{aligned}
$$

Jadi Rata-rata tingkat pemahaman guru terhadap standar isi berdasarkan jawaban responden yakni 1,97. Dengan rata-rata ini bila dikonversikan dengan skala 5 maka perhitungannya sebagai berikut;

$$
\begin{aligned}
\overline{N i}= & \frac{\sum X}{\text { skormaksimal }} \times 5 \\
& =\frac{1,97}{4} \times 5 \\
& =2,47
\end{aligned}
$$

Dengan nilai rata-rata 2,47 dalam skor lima, berdasarkan kriteria penilaian pada Tabel 2 maka pemahaman guru terhadap standar isi termasuk dalam kategori kurang. Adapun rincian skor nilai setiap responden pada komponen 1 ini dapat dilihat di Gambar 2. Hasil konversi ini menunjukkan bahwa dari 116 guru ada 7 orang atau $6,03 \%$ yang memperoleh nilai sangat kurang, 64 orang atau 55,17\% yang memperoleh nilai kurang, 45 orang atau 38,79\% yang memperoleh nilai cukup, tidak ada yang memperoleh nilai baik dan sangat baik seperti pada grafik berikut.

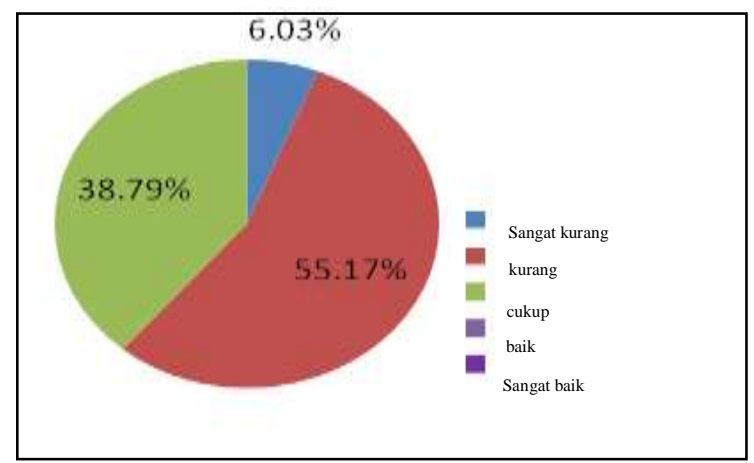

Gambar 1. Pemahaman Guru tentang Standar Isi dalam KTSP

Dengan keadaan yang sedemikian rendahnya pemahaman guru tentang standar isi dalam KTSP, maka dapat diprediksikan bahwa pelaksanaan KTSP di sekolah juga sangat rendah, karena guru hanya mampu melaksanakannya sesuai dengan apa yang dipahaminya. 
Rendahnya pemahaman guru ini berpengaruh terhadap pelaksanaan KTSP di sekolah, berupa penyusun perangkat pembelajaran (silabus dan RPP), pelaksanaan kegiatan pembelajaran, dan mengevaluasi kegiatan pembelajaran, yang dapat dilihat dari hasil penelitian ini tentang implementasi KTSP. Hasil penelitian juga menunjukkan bahwa kemampuan mengimplementasikan KTSP hanya mencapai nilai rata-rata 2,41 dalam skor lima.

Rendahnya pemahaman guru tentang standar isi ini dipengaruhi oleh kurangnya sosialisasi tentang KTSP kepada guru, kurangnya ketersediaan buku-buku tentang KTSP yang dapat dibaca oleh guru, dan juga rendahnya motivasi guru itu sendiri dalam pelaksanaan KTSP. Faktor motivasi ini dapat menjadi penyebab utama dalam persoalan ini, karena bila dari dalam diri guru sendiri ada motivasi yang kuat untuk melaksanakan KTSP, maka guru tentu dapat mengatasi persoalan rendahnya pemahaman terhadap standar isi ini dengan mencari dan berusaha untuk menemukan apa yang belum dipahaminya, demi kepentingan pelaksanaan tugasnya sebagai guru.

Kenyataan di atas tidak sejalan dengan apa yang disampaikan Mulyasa (2004, pp.1329) tentang tujuh (7) jurus sukses implementasi KTSP, yang diantaranya: mensosialisasikan perubahan kurikulum, mengubah paradigma (pola pikir) guru, dan memberdayakan tenaga kependidikan. Untuk dapat menjalankan kurikulum di sekolah dengan optimal, perlu sosialisasi yang cukup kepada pelaksana kurikulum yaitu guru. Guru harus memperoleh pengetahuan yang benar dan memadai tentang kurikulum yang sedang dilaksanakan. Pola pikir atau paradigma guru harus diubah sesuai denga kurikulum yang sedang berjalan. Pola pikir atau paradigma juga menyangkut motivasi dan kemauan guru. Intinya bahwa untuk melaksanakan kurikulum, persiapan yang harus dilakukan adalah melakukan sosialisasi yang cukup untuk memberikan pemahaman yang mendalam bagi guru dalam melaksanakan kurikulum, dan guru harus dipersiapkan dengan matang baik itu dari aspek pengetahuan, motivasi, kreativitas maupun kemampuan mengajarnya untuk melaksanakan kurikulum tersebut.

Namun hasil penelitian menunjukkan bahwa yang terjadi di lapangan sangat jauh dari harapan. Pengetahuan guru tentang kurikulum tidak dipersiapkan dengan baik. Banyak guru tidak memahami kurikulum yang dilaksanakannya. Pola pikir guru tidak diarahkan untuk me- laksanakan pembelajaran demi pencapaian kompetensi pada siswa, niat dan motivasi guru untuk melaksanakan kurikulum sangat rendah.

Dengan kondisi yang demikian memang tidak mengherankan bila pelaksanaan KTSP di sekolah belum dapat berjalan dengan optimal. Karena itu, sebelum melaksanakan suatu program, dalam hal ini KTSP, perlu diberikan sosialisasi yang memadai kepada para pelaksana program yakni guru sebagai pelaksana KTSP di sekolah. Dengan sosialisasi yang cukup dan informasi yang lengkap, memberikan pemahaman yang mendalam dan lengkap tentang program yang dilaksanakan. Dengan demikian program yang direncanakan dapat dilaksanakan dengan optimal.

Mengingat bahwa pemerintah sedang merencanakan perubahan kurikulum dari KTSP ke kurikulum 2013, maka diharapkan sebelum pelaksanaan kurikulum tersebut, perlu diberikan sosialisasi yang memadai bagi guru sebagai pelaksana kurikulum di sekolah. Mengubah paradigma guru sesuai dengan tujuan yang akan dicapai oleh kurikulum. Selain sosialisasi, perlu disiapkan buku-buku petunjuk pelaksanaan kurikulum dalam jumlah yang cukup dan mudah diperoleh guru, agar membantu guru dalam memahami dengan benar tentang kurikulum yang dilaksanakannya.

Kemampuan Guru Mengimplementasikan KTSP pada Sekolah Dasar di Kecamatan Detukeli Kabupaten Ende

Kemampuan guru dalam mengimplementasikan KTSP dikaji dalam 3 bagian yaitu pada kemampuan menyusun perangkat pembelajaran berupa silabus dan Rencana Pelaksanaan Pembelajaran (RPP), pelaksanaan kegiatan pembelajaran dalam kelas, dan pelaksanaan evaluasi kegiatan pembelajaran. Ketiga bagian ini mendapat porsi paling banyak dalam item penelitian, yakni sebanyak 71 item penelitian. Dari 71 item ini terdiri dari 24 item pada bagian kemampuan menyusun perangkat pembelajaran berupa silabus dan Rencana Pelaksanaan Pembelajaran (RPP), 47 item pada bagian pelaksanaan kegiatan pembelajaran dalam kelas, dan 10 item pada bagian pelaksanaan evaluasi kegiatan pembelajaran.

\section{Kemampuan Menyusun Silabus dan RPP}

Bagian pertama dari kemampuan mengimplementasikan KTSP yakni kemampuan menyusun silabus dan RPP. Pada komponen ini, ada 24 item penelitian dan semuanya di- 
jawab oleh responden. Total skor ideal terendah pada komponen ini 24 dan skor ideal tertinggi adalah 96. Data penelitian menunjukkan skor terendah dari responden 38 dan skor tertingginya adalah 53. Dari skor tersebut dapat dihitung rata-rata terendah dari responden adalah 1,58 dan rata-rata tertinggi adalah 2,21 . Total rata-rata jawaban masing-masing responden untuk semua item pada komponen ini adalah 220,33. Dari total rata-rata jawaban responden ini dibagi jumlah responden 116.

$$
\begin{aligned}
\bar{x} & =\frac{\sum \bar{x} i}{n} \\
& =\frac{220,33}{116} \\
& =1,90
\end{aligned}
$$

Jadi rata-rata tingkat kemampuan guru Kecamatan Detukeli dalam penyusunan silabus dan RPP yakni 1,90. Dengan rata-rata ini bila dikonversikan dengan skala 5 maka perhitungannya sebagai berikut;

$$
\begin{aligned}
\overline{N i} & =\frac{\sum X}{\text { skormaksimal }} \times 5 \\
& =\frac{1,90}{4} \times 5 \\
& =2,374
\end{aligned}
$$

Dengan nilai rata-rata 2,374 dalam skor lima maka berdasarkan kriteria penilaian pada Tabel 7 maka kemampuan guru dalam menyusun silabus dan RPP termasuk dalam kategori kurang. Adapun rincian skor nilai setiap responden pada komponen 2 ini dapat dilihat pada gambar 3. Hasil konversi ini menunjukkan bahwa dari 116 guru; tidak ada guru yang memperoleh nilai sangat kurang, 110 orang atau 94,83\% yang memperoleh nilai kurang, 6 orang atau $5,17 \%$ yang memperoleh nilai cukup yang memperoleh nilai, tidak ada yang memperoleh nilai baik dan sangat baik.

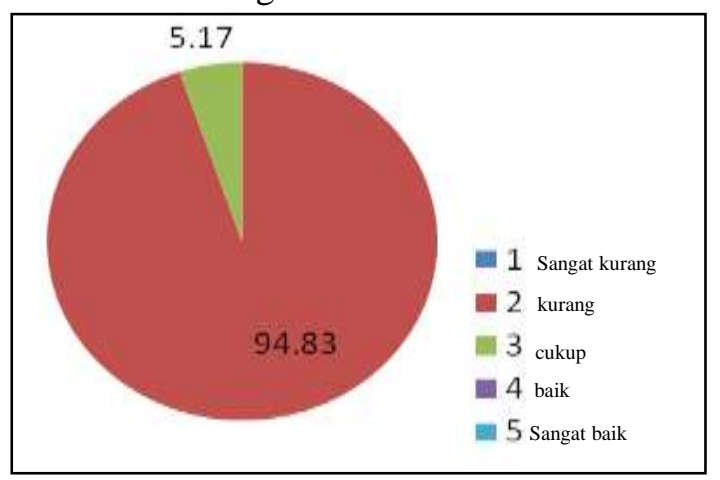

Gambar 2. Kemampuan Menyusun Silabus dan RPP
Kemampuan Melaksanakan Kegiatan Pembelajaran

Bagian kedua dari komponen implementasi KTSP yakni kemampuan melaksanakan kegiatan pembelajaran. Pada komponen ini, ada 37 item penelitian dan semuanya dijawab oleh responden. Total skor ideal terendah pada komponen ini 37 dan skor ideal tertinggi adalah 148. Data penelitian menunjukkan skor terendah dari responden 60 dan skor tertingginya adalah 84. Dari skor tersebut dapat dihitung rata-rata terendah dari responden adalah 1,62 dan rata-rata tertinggi adalah 2,27. Total ratarata jawaban responden untuk semua item pada komponen ini adalah 225,57. Dari total rata-rata jawaban responden ini dibagi jumlah responden 116.

$$
\begin{aligned}
\bar{x} & =\frac{\sum x_{\bar{i}}}{n} \\
& =\frac{225,57}{116} \\
& =1,94
\end{aligned}
$$

Jadi Rata-rata tingkat kemampuan guru kecamatan Detukeli dalam pelaksanaan pembelajaran di kelas yakni 1,94. Dengan rata-rata ini bila dikonversikan dengan skala 5 maka perhitungannya sebagai berikut;

$$
\begin{aligned}
\overline{N i} & =\frac{\sum X}{\text { skormaksimal }} \times 5 \\
& =\frac{1,94}{4} \times 5 \\
& =2,431
\end{aligned}
$$

Dengan nilai rata-rata 2,431 dalam skor lima maka berdasarkan kriteria penilaian pada tabel 7, maka kemampuan guru dalam melaksanakan kegiatan pembelajaran, termasuk dalam kategori kurang. Adapun rincian skor nilai setiap responden pada komponen 3 ini dapat dilihat pada gambar 4. Hasil konversi ini menunjukkan bahwa dari 116 guru; tidak ada guru yang memperoleh nilai sangat kurang, 102 orang atau $87,93 \%$ yang memperoleh nilai kurang, 14 orang $12,07 \%$ yang memperoleh nilai cukup, tidak ada yang memperoleh nilai baik dan sangat baik. 


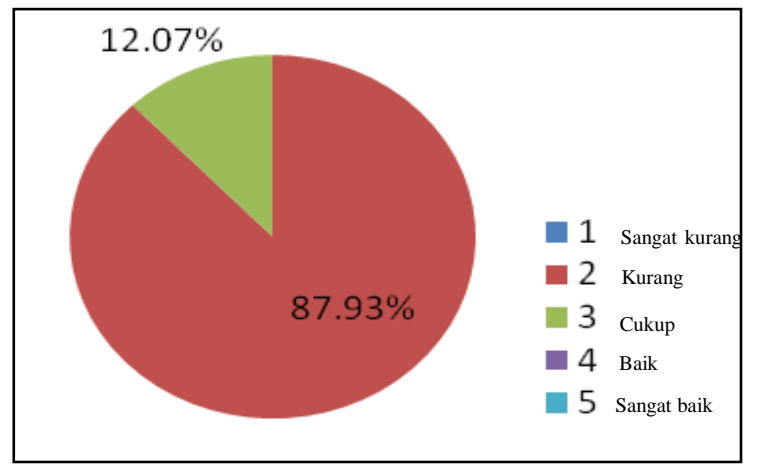

Gambar 3. Kemampuan Melaksanakan

Kegiatan pembelajaran

Kemampuan Melaksanakan Evaluasi terhadap Kegiatan Pembelajaran

Bagian terakhir dari komponen implementasi KTSP yakni kemampuan melaksanakan evaluasi terhadap kegiatan pembelajaran dalam kelas. Pada komponen ini, ada 10 item penelitian dan semuanya dijawab oleh responden. Total skor ideal terendah pada komponen ini adalah 10 dan skor ideal tertinggi adalah 40 . Data penelitian menunjukkan skor terendah dari responden 13 dan skor tertingginya adalah 24 . Dari skor tersebut dapat dihitung rata-rata terendah dari responden adalah 1,30 dan rata-rata tertinggi adalah 2,40. Total rata-rata jawaban responden untuk semua item pada komponen ini adalah 226,40. Total jawaban setiap item selanjutnya dibagi jumlah responden 116.

$$
\begin{aligned}
\bar{x} & =\frac{\sum \bar{x} i}{n} \\
& =\frac{226,40}{116} \\
& =1,95
\end{aligned}
$$

Jadi Rata-rata tingkat kemampuan guru kecamatan Detukeli dalam pelaksanaan evaluasi kegiatan pembelajaran di kelas berdasarkan jawaban responden yakni 1,95 . Dengan rata-rata kemampuan 1,95 ini bila dikonversikan dengan skala 5 maka perhitungannya sebagai berikut;

$$
\begin{aligned}
\overline{N i} & =\frac{\sum X}{\text { skormaksimal }} \times 5 \\
& =\frac{1,95}{4} \times 5 \\
& =2,440
\end{aligned}
$$

Dengan nilai rata-rata 2,440 dalam skor lima, berdasarkan kriteria penilaian pada Tabel 7 maka kemampuan guru melaksanakan evaluasi kegiatan pembelajaran termasuk dalam kategori kurang. Adapun rincian skor nilai setiap responden pada komponen 1 ini dapat dilihat pada gambar 5. Hasil konversi ini menunjukkan bahwa dari 116 guru; 1 orang atau $0,86 \%$ yang memperoleh nilai sangat kurang, 36 orang $31,03 \%$ yang memperoleh nilai kurang, 79 orang atau $68,10 \%$ yang memperoleh nilai cukup, tidak ada yang memperoleh nilai baik dan sangat baik.

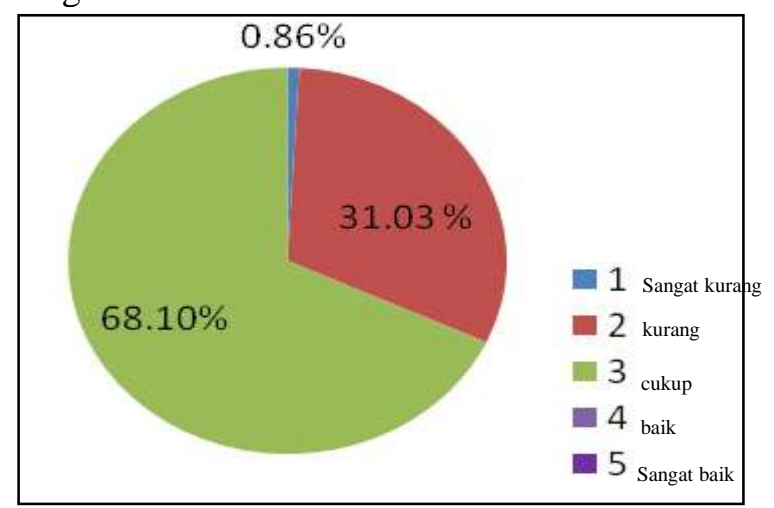

Gambar 4. Kemampuan Melaksanakan

Evaluasi Kegiatan pembelajaran

Secara umum pada bagian kemampuan mengimplementasikan KTSP dengan 71 item penelitian, total skor terendah ideal 71 dan skor tertinggi ideal adalah 284. Data penelitian menunjukkan skor terendah dari responden 118 dan skor tertingginya adalah 154. Pada komponen 2 yang terdiri dari kemampuan menyusun perangkat pembelajaran berupa silabus dan Rencana Pelaksanaan Pembelajaran (RPP), pelaksanaan kegiatan pembelajaran dalam kelas, dan pelaksanaan evaluasi kegiatan pembelajaran dapat dihitung rata-ratanya dengan mengakumulasikan rata-rata dari ketiga bagian penelitian tersebut. Total rata-rata dalam skor 5 dari ketiga bagian ini adalah 7,24

$$
\begin{aligned}
\bar{x} & =\frac{\sum \bar{x} i}{n} \\
& =\frac{7,24}{3} \\
& =2,41
\end{aligned}
$$

Dengan nilai rata-rata 2,41 dalam skor lima, berdasarkan kriteria penilaian maka kemampuan guru mengimplementasikan KTSP pada sekolah dasar di Kecamatan Detukeli dikatakan kurang. Hasil konversi ini menunjukkan bahwa dari 116 guru; tidak ada guru yang memperoleh nilai sangat kurang, 108 orang $94,83 \%$ yang memperoleh nilai kurang, 8 orang $5,17 \%$ yang memperoleh nilai cukup yang memperoleh nilai, tidak ada yang memperoleh nilai baik dan sangat baik. 


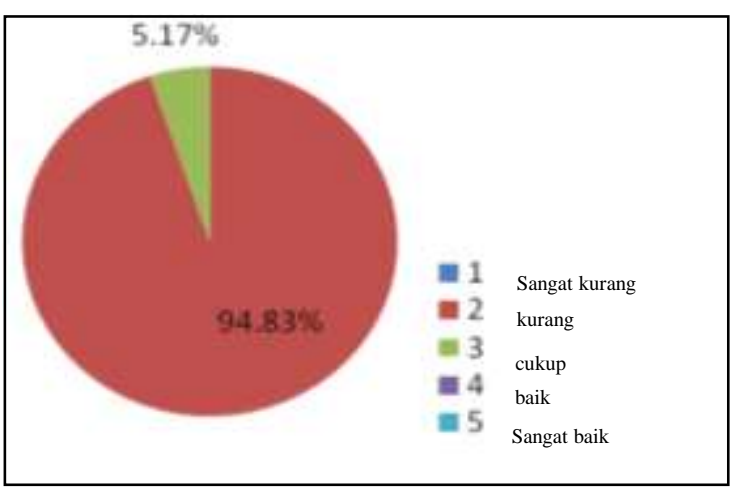

Gambar 5. Kemampuan Mengimplementasikan KTSP

Berdasarkan gambaran di atas maka jelas bahwa pelaksanaan KTSP di sekolah belum berjalan sesuai dengan harapan. Ada 94,83\% guru yang memiliki kemampuan menyusun perangkat pembelajaran kurang. Bahkan lebih dari itu, hasil penelitian menunjukkan, ada guru yang tidak membuat rencana pembelajaran untuk setiap pertemuan sesuai jadwal di satuan pendidikan. Keadaan ini berdampak pada pelaksanaan pembelajaran di kelas.

Tentang RPP yang lengkap, Mulyasa (2007, pp.255-258) mengungkapkan pada umumnya pelaksanaan pembelajaran berbasis KTSP mencakup tiga hal: (a) Pretest (tes awal), (b) Pembentukkan kompetensi, dan (c) Posttest (tes akhir). Dengan kemampuan membuat perangkat pembelajaran yang minim ini, jelas guru tidak melakukan perencanaan yang matang untuk kegiatan pembelajaran yang dilaksanakannya di kelas bersama siswanya. Pembelajaran di kelas berjalan tanpa arah dan tujuan yang jelas, yang tentunya sangat berpengaruh terhadap pencapaian kompetensi siswa terhadap materi yang dipelajarinya.

Dalam Permendiknas No. 41 Tahun 2007 tentang standar proses untuk satuan pendidikan dasar dan menengah telah diatur mengenai syarat pelaksanaan proses pembelajaran serta kegiatan dalam pembelajaran. Pelaksanaan pembelajaran merupakan implementasi dari RPP. Pelaksanaan pembelajaran meliputi kegiatan pendahuluan, kegiatan inti dan kegiatan penutup. Dengan perencanaan pelaksanaan pembelajaran yang tidak matang, tentunya juga berpengaruh terhadap pelaksanaan pembelajaran dan evaluasi kegiatan pembelajaran. Seluruh kegiatan pembelajaran hendaknya tertuang dalam RPP. Demikian juga dengan rencana pelaksanaan evaluasi pembelajaran (posttest) harus tertuang dalam Rencana Pelaksanaan Pembelajaran (RPP). Bila RPP tidak dibuat dengan baik, maka sudah sangat pasti pelaksanaan ke- giatan pembelajaran dan evaluasi pun tidak dibuat dengan baik. Dengan demikian guru tentu tidak dapat melaksanakan kegiatan pembelajaran dengan benar dan mengevaluasi dengan tepat apa yang seharusnya dievaluasi dari pembelajaran yang dilaksanakannya.

Suatu kenyataan yang tidak dapat diingkari bahwa semuanya ini bermula dari rendahnya pemahaman guru tentang kurikulum yang dilaksanakannya. Rendahnya pemahaman guru tentang KTSP ini sendirilah yang merupakan dasar yang rapuh untuk pelaksanaan KTSP. Selain faktor pemahaman yang rendah tentang KTSP, rendahnya tingkat kerja sama antara guru dalam KKG turut mempengaruhi pelaksanaan kurikulum di sekolah. Bila ada kerja sama antara guru, tentu di antara guru dapat saling melengkapi kekurangan dan dapat memperbaiki rencana pelaksanaan pembelajaran dan juga pelaksanaan pembelajaran.

Selain kedua faktor di atas, kerja sama antara guru dengan kepala sekolah, keterlibatan komite, ketersediaan buku pelajaran dan fasilitas penunjang kegiatan belajar juga turut mempengaruhi kegiatan pembelajaran yang dilaksanakan guru di sekolah. Rendahnya sumber daya manusia dan juga tidak ditunjang oleh komponen lainnya menyebabkan pelaksanaan KTSP di sekolah menjadi sangat tidak optimal.

Melihat kondisi yang ada, memang sangat tidak mungkin pelaksanaan kurikulum tingkat satuan pendidikan yang sudah berjalan sekian tahun ini hanyalah menjadi suatu rutinitas tak bermakna bagi siswa. Siswa ke sekolah tetapi tidak mendapatkan pengetahuan atau kompetensi lebih. Kegiatan pembelajaran yang mereka jalani tidak memberikan pengalaman belajar yang bermakna untuk meningkatkan kompetensi dalam diri siswa.

Untuk keluar dari situasi ini tentu tidaklah mudah. Perencana program atau kurikulum perlu menyiapkan semuanya dengan matang, mulai dari sosialisasi yang memadai bagi guru, ketersediaan dana yang mencukupi untuk pelaksanaan kurikulum, dan juga menyediakan fasilitas yang memadai untuk menunjang pelaksanaan kurikulum. Perencana kurikulum harus benar-benar memahami kondisi lapangan dan juga guru sebagai pelaksana kurikulum di lapangan. Dengan tingkat pendidikan yang belum semuanya diploma atau sarjana, menyebabkan lambannya pemahaman guru terhadap kurikulum. Karena itu, sosialisasi tidak dapat hanya dilakukan dengan 1 atau 2 kali saja. Sosialisasi harus dilakukan secara perlahan dan diberikan 
penjelasan sedetail mungkin, agar bisa dipahami dengan benar.

Perencana kurikulum perlu mempertimbangkan untuk menyiapkan tenaga pendamping yang benar-benar mahir dengan kurikulum yang sedang berjalan untuk melakukan pendampingan bagi guru dalam pelaksanaan di tahap awal dan sekaligus untuk melakukan supervisi ketika guru sudah bisa melaksanakan sendiri. Supervisi dipandang perlu karena dengan tingkat rutinitas yang cukup tinggi membuat guru bosan ataupun jenuh, sehingga pelaksanaan kurikulum bisa diabaikan oleh guru. Dengan pendampingan dan supervisi yang terus menerus, diharapkan dapat menjadi dorongan kuat bagi guru dalam melaksanakan kurikulum.

Faktor Penunjang dan Faktor Penghambat Pelaksanaan KTSP pada Sekolah Dasar di Kecamatan Detukeli

Komponen penelitian tentang faktor penunjang dan faktor penghambat pelaksanaan KTSP pada sekolah dasar di Kecamatan Detukeli dalam instrumen penelitian ada 14 item penelitian dan semuanya dijawab oleh responden. Hasil penelitian pada komponen ini dapat dilihat pada lihat pada tabel berikut:

Tabel 3. Persentase Peringkat Ketidaktersediaan Faktor Penunjang Pelaksanaan KTSP

\begin{tabular}{|c|c|c|c|c|c|}
\hline \multirow{2}{*}{ No Urut } & \multirow{2}{*}{ Faktor Penunjang Pelaksanaan KTSP } & \multicolumn{4}{|c|}{ Jawaban Responden dalam Persen (\%) } \\
\hline & & Tidak Ada & Kurang & Cukup & Banyak/Baik \\
\hline 1 & Ketersediaan dana untuk pelaksanaan KTSP & 43.10 & 56.90 & 0 & 0 \\
\hline 2 & Ketersediaan media pembelajaran & 40.52 & 59.48 & 0 & 0 \\
\hline 3 & $\begin{array}{l}\text { Ketersediaan buku-buku tentang KTSP di } \\
\text { perpusatakaan sekolah }\end{array}$ & 36.21 & 63.79 & 0 & 0 \\
\hline 4 & $\begin{array}{l}\text { Kerja sama antara sekolah dan komite dalam pelaksa- } \\
\text { naan KTSP }\end{array}$ & 35.34 & 64.66 & 0 & 0 \\
\hline 5 & $\begin{array}{l}\text { Ketersediaan buku sumber lainnya yang materi } \\
\text { pelajaran }\end{array}$ & 34.48 & 65.52 & 0 & 0 \\
\hline 6 & $\begin{array}{l}\text { Kemauan/niat guru untuk melaksanakan KTSP di } \\
\text { sekolah }\end{array}$ & 33.62 & 66.38 & 0 & 0 \\
\hline 7 & $\begin{array}{l}\text { Kerja sama antara guru dalam KKG dalam pelaksanaan } \\
\text { KTSP }\end{array}$ & 30.17 & 69.83 & 0 & 0 \\
\hline 8 & Ketersediaan buku pedoman pelaksanaan KTSP & 29.31 & 70.69 & 0 & 0 \\
\hline 9 & Ketersedian buku pelajaran & 29.31 & 70.69 & 0 & 0 \\
\hline 10 & Ketersediaan alat peraga pembelajaran & 29.31 & 70.69 & 0 & 0 \\
\hline 11 & $\begin{array}{l}\text { Kerja sama antara guru dengan kepala sekolah dalam } \\
\text { pelaksanaan KTSP }\end{array}$ & 29.31 & 70.69 & 0 & 0 \\
\hline 12 & $\begin{array}{l}\text { Sosialisasi tentang KTSP dari Dinas Kabupaten ke } \\
\text { guru }\end{array}$ & 27.59 & 72.41 & 0 & 0 \\
\hline 13 & $\begin{array}{l}\text { Keterlibatan komite dalam menyediakan sarana dan } \\
\text { pra-sarana yang menunjang kegiatan pembelajaran }\end{array}$ & 27.59 & 72.41 & 0 & 0 \\
\hline 14 & Keterlibatan komite sekolah dalam penyusunan KTSP & 25.86 & 74.14 & 0 & 0 \\
\hline
\end{tabular}

Dari detail frekuensi dan persentasi jawaban responden di atas sudah bisa terlihat betapa terbatasnya ketersediaan faktor-faktor penunjang pelaksanaan KTSP di sekolah dasar sekecamatan Detukeli. Rendahnya ketersediaan faktor-faktor yang diharapkan dapat menunjang pelaksanaan KTSP ini justru menjadi faktor penghambat dalam pelaksanaan KTSP. Hasil penelitian menunjukkan bahwa faktor penghambat dalam Pelaksanaan KTSP di sekolah dasar di kecamatan Detukeli yaitu:

Ketersediaan dana merupakan faktor yang menempati peringkat tertinggi dalam persentasi jawaban responden yang mengatakan faktor tersebut tidak tersedia. Ada 43,10\% res- ponden mengatakan tidak ada dana yang disediakan untuk pelaksanaan KTSP dan 56,90\% mengatakan dana itu tersedia tetapi kurang. Pada peringkat kedua yakni ketersediaan media pembelajaran dengan $40,52 \%$ yang mengatakan tidak ada media pembelajaran yang tersedia di sekolah dan 59, 48\% mengatakan media pembelajaran yang tersedia masih kurang.

Selanjutnya ketersediaan buku-buku tentang KTSP di perpusatakaan sekolah ada $36,21 \%$ yang mengatakan tidak tersedia, dan $63,79 \%$ mengatakan ada tetapi masih kurang. Ada 35,34\% responden mengatakan tidak ada kerja sama antara sekolah dan komite dalam pelaksanaan KTSP dan sisanya $64,66 \%$ ada ker- 
ja sama antara sekolah dan komite dalam pelaksanaan KTSP tetapi masih kurang. Sementara itu pada faktor ketersediaan buku sumber lainnya yang materi pelajaran, ada $34,48 \%$ mengatakan tidak ada dan $65,52 \%$ responden mengatakan masih kurang. Tentang kemauan/niat guru untuk melaksanakan KTSP di sekolah, ada $33,62 \%$ responden mengatakan tidak ada dan $66,38 \%$ mengatakan masih kurang. Menyusul faktor kerja sama antara guru dalam KKG dalam pelaksanaan KTSP, ada 30,17\% mengatakan tidak ada kerja sama, dan 69,83\% mengatakan ada kerja sama namun masih kurang.

Sementara faktor ketersediaan buku pedoman pelaksanaan KTSP, ketersedian Buku pelajaran dan ketersediaan alat peraga pembelajaran, ketiganya berada pada peringkat yang sama yakni dengan $29,31 \%$ responden menga- takan tidak ada dan 70,69\% responden mengatakan ada namun masih kurang. Faktor kerja sama antara guru dengan kepala Sekolah dalam pelaksanaan KTSP, ada 29,31\% mengatakan tidak ada dan 70,69\% mengatakan masih kurang. Untuk faktor sosialisasi tentang KTSP dari Dinas Kabupaten ke guru, ada 27,59\% responden mengatakan tidak ada dan $72,41 \%$ mengatakan masih kurang.

Tentang faktor keterlibatan komite dalam menyediakan sarana dan prasarana yang menunjang kegiatan pembelajaran, ada 27,59\% responden mengatakan tidak ada dan $72,41 \%$ mengatakan kurang. Dan faktor yang menempati peringkat paling akhir yakni keterlibatan komite sekolah dalam penyusunan KTSP, ada $25,86 \%$ responden mengatakan tidak ada dan $74,14 \%$ responden mengatakan kurang.

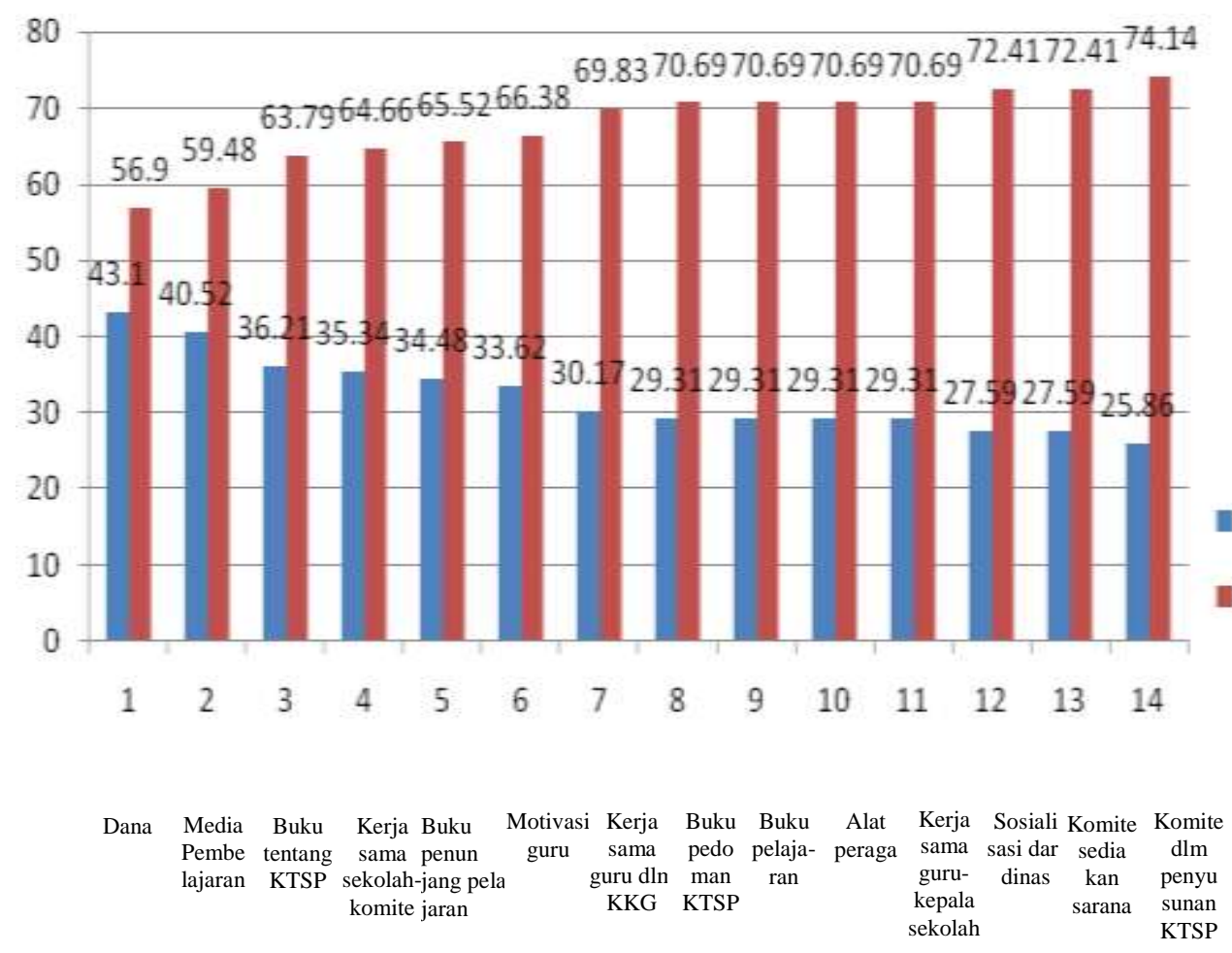

Gambar 7. Persentasi Ketersediaan Faktor Penunjang Pelaksanaan KTSP

Komponen penelitian tentang Faktor Penunjang dan Faktor Penghambat Pelaksanaan KTSP, hasil penelitian menunjukkan bahwa ketersediaan faktor penunjang pelaksanaan KTSP di sekolah tidak ada dan kalaupun ada tetapi masih kurang. Tidak ada responden yang mengatakan bahwa ketersediaan faktor-faktor itu cukup dan baik atau banyak.

Pelaksanaan suatu program tentunya optimal jika ditunjang dengan baik oleh faktorfaktor penunjang lainnya. Ketidaktersediaan faktor-faktor penunjang tersebut justru menjadi penghambat bagi pelaksanaan program tersebut. Demikian juga dengan pelaksanaan KTSP di sekolah. Dengan rendahnya ketersediaan faktor-faktor penunjang pelaksanaan KTSP justru menjadi penghambat untukn pelaksanaan KTSP itu sendiri.

Ketersediaan faktor penunjang pelaksanaan KTSP di Kecamatan Detukeli sangat terbatas, baik itu ketersediaan fasilitas, berupa: buku-buku tentang KTSP, Buku pelajaran, media dan alat peraga pembelajaran, dan juga dana untuk pelaksanaan KTSP; maupun rendahnya 
kerja sama antara; Guru dalam KKG, guru dengan kepala sekolah, komite sekolah dengan sekolah, sekolah dengan dinas. Dan lebih dari itu faktor motivasi dari dalam diri guru untuk melaksanakan KTSP dan sosialisasi yang kurang. Semuanya ini justru menjadi penghambat yang sangat mempengaruhi pelaksanaan KTSP di sekolah. Kenyataan ini bertentangan dengan apa yang disampaikan Fiske (1998, p.29) mengatakan bahwa; "untuk memperbaiki mutu pendidikan perlu memberikan kepada masyarakat kesempatan yang lebih besar untuk urun pendapat dalam mengelola sekolah-sekolah mereka." Keterlibatan guru, komite sekolah dan masyarakat sangat minim, menyebabkan mereka tidak memahami apa yang harus dilaksanakan. Mereka tidak tidak bersahabat dengan kurikulum yang sedang mereka jalani.

Dengan kondisi riil seperti ini, maka untuk pelaksanaan kurikulum ke depan, perlu didahului dengan kajian yang mendalam tentang situasi lapangan. Perencana kurikulum tidak dapat menyamakan kondisi di daerah dengan tempat kurikulum direncanakan. Untuk perubahan kurikulum ke depan, sebagai suatu bentuk inovasi di bidang pendidikan agar mudah diterima dan dilaksanakan, maka perencana kurikulum dapat menyiapkannya beberapa hal yang disampaikan Sanjaya (2011, pp.323324) berikut: Faktor pembiayaan (cost), Inovasi mudah diterima bila bersifat sederhana dan mudah dikomunikasikan (kompleksitas), inovasi mudah dilaksanakan, sesuai dengan kebutuhan, tingkat pengetahuan, dan keyakinan penggunanya (kompabilitas), inovasi terlebih dahulu harus diujicobakan secara ilmiah sehingga dapat dipertanggungjawabkan, inovasi yang dalam penyusunannya melibatkan penggunanya, inovasi perlu disosialisasikan untuk diketahui dan dipahami oleh penggunanya. Karena itu, tingkat keahlian dan kemampuan penyuluh sangat dibutuhkan dalam mensosialisasikan inovasi tersebut.

\section{Simpulan dan Saran}

Simpulan

Pemahaman guru tentang KTSP pada Sekolah Dasar di Kecamatan Detukeli Kabupaten Ende masih rendah dengan rata-rata tingkat pemahaman 1,97 berdasarkan frekuensi jawaban responden, atau dengan nilai 2,462 dalam skor lima.

Kemampuan guru mengimplementasikan KTSP pada Sekolah Dasar di Kecamatan
Detukeli Kabupaten Ende masih rendah. Kemampuan mengimplementasikan ini terdiri dari; (a) Kemampuan dalam penyusunan silabus dan RPP masih rendah dengan rata-rata tingkat kemampuan 1,90 berdasarkan frekuensi jawaban responden, atau dengan nilai 2,374 dalam skor lima; (b) Kemampuan dalam pelaksanaan pembelajaran di kelas masih rendah dengan rata-rata tingkat kemampuan 1,90 berdasarkan frekuensi jawaban responden, atau dengan nilai 2,374 dalam skor lima; (c) Kemampuan melaksanakan evaluasi kegiatan pembelajaran di kelas nasih rendah dengan rata-rata tingkat kemampuan 1,95 berdasarkan frekuensi jawaban responden, atau dengan nilai 2,440 dalam skor lima.

Ketersediaan faktor penunjang dalam pelaksanaan KTSP pada Sekolah Dasar di Kecamatan Detukeli, seperti; dana, media dan alat peraga, buku pelajaran, buku pedoman KTSP, kerja sama antara, kepala sekolah, guru, komite sekolah dan dinas, dan sosialisasi KTSP untuk guru sangat kurang. Ketersediaan faktor-faktor tersebut yang sangat terbatas bahkan tidak ada.

Saran

Untuk Guru Sekolah Dasar: tingkatkan motivasi dari dalam diri sendiri dalam menjalankan tugas secara profesional, dengan melakukan persiapan yang matang untuk pelaksanaan kegiatan pembelajaran di kelas, mendalami kurikulum yang berlaku, membuat silabus dan rencana pelaksanaan pembelajaran secara benar dan sesuai dengan kurikulum yang berlaku. Guru harus membangun kerja sama dengan sesama guru dalam KKG, Kepala sekolah dan Komite Sekolah untuk menunjang pelaksanaan kurikulum.

Kepala Sekolah: membangun kerja sama dengan guru, komite sekolah dan Dinas Pendidikan, Pemuda dan olahraga dalam menunjang pelaksanaan kurikulum, melakukan supervisi bagi guru dalam pelaksanaan kurikulum di sekolah.

Dinas Pendidikan: Pemuda dan Olahraga, dan Pemerintah Daerah: memberikan sosialisasi yang memadai tentang kurikulum bagi guru di sekolah, dan secara terus menerus melakukan supervisi untuk membantu pengawasan pelaksanaan kurikulum. Pemerintah Daerah perlu menyiapkan dana yang memadai untuk pengadaaan fasilitas menunjang pelaksanaan kurikulum, dan juga dana untuk pelaksanaan kurikulum itu sendiri. 
Komite Sekolah: melibatkan diri secara aktif untuk memenuhi kebutuhan sekolah dalam pelaksanaan kurikulum yang berlaku.

Lembaga Pendidikan Tenaga Kependidikan: untuk membekali calon tenaga kependidikan dengan pengetahuan yang memadai tentang kurikulum. Terlibat secara aktif bersama guru di sekolah untuk pelaksanaan kurikulum di sekolah.

Perencana kurikulum, untuk pelaksanaan kurikulum ke depan, perlu didahului dengan kajian yang mendalam tentang situasi lapangan, agar kurikulum yang diprogramkan dapat dilaksanakan dengan optimal sampai dengan di daerah terpencil.

\section{Daftar Pustaka}

Arikunto, S. \& Jabar, C.S.A. (2004). Evaluasi program pendidikan. pedoman teoretis praktis bagi praktisi pendidikan. Jakarta: Rineka Cipta.

Delors, J. et al. (1996). Learning: The treasure within. Paris: UNESCO. http://www.unesco.org/delors/delors_e.pdf Diakses 17 Pebruari 2013.

Fiske, E.B. (1998). Desentralisasi pengajaran; Politik dan konsensus. Jakarta: Grasindo.
Mulyasa, E. (2004). Implementasi kurikulum berbasis kompetensi, panduan pembelajaran kurikulum berbasis kompetensi. Bandung: PN. PT. Remaja Rosdakarya.

Rogers, E.M. (1993). Diffusion of Innovations. 4th Edition. The free press. New York. http://books.google.co.id/books?id=vlii $4 Q s B 7 j I C \& p g=P A 10 \& l p g=P A 10 \& d q$ $=$ four + main + element + in + the + diffusio $n+o f+$ innovation \& source $=b l \& o t s=D J$ $Y$ syOQr7R\&sig $=$ CaMXrtgn_bv96oQM $4 b z x j l t d K k \& h l=i d \& s a=X \& e i=2 R 5 a U b$ W6KYTVrQfwvoCABw\&redir_esc $=y \# v$ $=$ onepage $\& q=$ four $\% 20$ main $\% 20$ eleme nt\%20in\%20the\%20diffusion\%20of\%2 Oinnovation $\& f=$ false.

Sanjaya, W. (2011). Kurikulum dan pembelajaran, teori dan praktek pengembangan Kurikulum Tingkat Satuan Pendidikan (KTSP). Jakarta: Kencana Prenada Media Group.

Tilaar, H.A.R. (2002). Pendidikan untuk masyarakat Indonesia Baru. Jakarta: PN. Grasindo.

Widoyoko, E.P. (2012). Teknik penyusunan instrumen penelitian. Yogyakarta: Pustaka Pelajar. 